Marquette University

e-Publications@Marquette

College of Nursing Faculty Research and

Publications

Nursing, College of

$12-1-2016$

\title{
The Role of Spirituality and Religiosity in Persons Living With Sickle Cell Disease
}

Dora L. Clayton-Jones

University of Wisconsin-Milwaukee, dora.clayton-jones@marquette.edu

Kristin Haglund

Marquette University, kristin.haglund@marquette.edu

Accepted version. Journal of Holistic Nursing, Vol. 34, No. 4 (December 2016): 351-360. DOI. (C) 2016 SAGE Publications. Used with permission. 


\title{
The Role of Spirituality and Religiosity in Persons Living with Sickle Cell Disease: A Review of the Literature
}

\author{
Dora Clayton-Jones \\ University of Wisconsin-Milwaukee, \\ Milwaukee, WI \\ Kristin Haglund, \\ College of Nursing, Marquette University \\ Milwaukee, WI
}

\begin{abstract}
Purpose: Sickle cell disease (SCD) is a serious debilitating chronic illness, affecting approximately 90,000 Americans and millions globally. Spirituality and religiosity (S/R) may ease the burden faced by persons living with SCD. The purpose of this study was to examine the role of $S / R$ in adolescents and adults living with SCD in the research literature. Method: The electronic databases Cumulative Index to Nursing and Allied Health Literature, Health Source Nursing/Academic, ProQuest Health Module, PsycINFO, Medline, PubMed, and the American Theological Library Association were searched from January 1995 to December 2014. Findings: Of the 89 studies retrieved, 11 articles between 2001 and 2013 met the inclusion criteria and were reviewed. Four themes emerged. The themes included (a) S/R as sources of

Journal of Holistic Nursing, Vol. 34, No. 4 (November 29, 2015) pp. 351-360. DOI. This article is (C SAGE Publications and permission has been granted for this version to appear in e-Publications@ Marquette. SAGE Publications does not grant permission for this article to be further copied/distributed or hosted elsewhere without the express permission from SAGE Publications.
\end{abstract}


coping, (b) S/R enhance pain management, (c) S/R influence health care utilization, and (d) S/R improve quality of life. Discussion: Use of S/R may be significant in coping with $S C D$, managing pain, affecting hospitalizations, and affecting quality of life. This review can direct researchers exploring $S / R$ in adolescents and adults living with SCD.

Keywords: adolescents, adults, children chronic conditions, spirituality, sickle cell disease

Sickle cell disease (SCD) is the most common autosomal recessive genetic disease in the United States, affecting approximately 70,000 to 100,000 Americans (National Institutes of Health, 2012). An estimated 113,098 hospitalizations and over 1 billion dollars in hospital costs are attributed to SCD annually (Kauf, Coates, Huazhi, ModyPatel, \& Hartzema, 2009; Steiner \& Miller, 2006). The hospital 30-day readmission rate for $\mathrm{SCD}$ is $31.9 \%$ and accounts for the highest readmission rate compared to all other diagnoses, including heart or renal failure (Elixhauser \& Steiner, 2013). SCD is a chronic debilitating disease that affects many systems, including cardiovascular, respiratory, digestive, lymphatic, endocrine, reproductive, urinary, integumentary, musculoskeletal, and the central nervous systems (Aygun, 2011; Pinckney \& Stuart, 2004; Rees, Williams, \& Gladwin, 2010). Symptoms and complications include pain, chronic anemia, disability, organ damage, increased risk for infection, and early death (Ignatavicus \& Workman, 2013). Frequent hospitalizations are common for many people living with SCD. Limitations of the hospital environment, such as social isolation and disruption of learning, pose challenges to academic achievement and overall development for children and adolescents. Children, adolescents, and adults with SCD experience symptoms, treatments, and complications of their condition that may hinder them in their physical, psychosocial, emotional, and academic functioning. These hindrances may be ameliorated through their spirituality and religiosity (S/R).

$S / R$ are related yet different. Spirituality includes a search for the sacred or transcendent (A. B. Cohen \& Koenig, 2003; Koenig, King, \& Carson, 2012). Spirituality may be experienced in a religious or a nonreligious setting (Waldron-Perrine et al., 2011). Spirituality is the innate capacity of humans to transcend themselves to discern and experience meaning and purpose in life beyond material, temporal existence through contemplation and action aimed ultimately toward 
the sacred (Benson, Roehlkepartain, \& Rude, 2003). Sacred refers to a divine being, ultimate reality, or ultimate truth as perceived by individuals (Larson, Swyers, \& McCullough, 1998). Religion is composed of an organized belief system and generally includes one's beliefs in relationship to the transcendent (Koenig et al., 2012). One can experience religion without spirituality (Waldron-Perrine et al., 2011). Religiosity refers to a commitment to an organized way of knowing and an orientation to a religious community's subject of worship (Schaefer, 2010).

People often draw from their S/R to cope with challenges (Mahoney, Pendleton, \& Ihrke, 2006; Pargament, Koenig, Tarakeshwar, \& Hahn, 2004). Such coping may be categorized as positive or negative religious coping. Positive religious coping fosters spiritual encouragement, optimistic redefining of negative circumstances, and mutual religious coping between the individual and God (Pargament, 1997). Negative religious coping includes elements of religious pain, discontent with the congregation and/or God, and negative religious reframing (Pargament, 1997). Both positive and negative religious coping may affect health outcomes.

When discussing spirituality, religiosity, and health, the emerging research of psychoneuroimmunology is of particular importance. Psychoneuroimmunology is the study of how psychological and physical stressors affect the neuroendocrine and immune systems (Koenig \& Cohen, 2002). One's responses to stressors such as interpersonal discord, chronic illnesses, or life events can affect physical and psychological well-being (S. Cohen, Kessler, \& Gordon, 1995). Responses to stressors may negatively affect neuroendocrine and immune functioning, which in turn, can impair the body's ability to resist disease. Psychological responses to stressors include anxiety or depression. Examples of physical responses to stressors include poor sleep, illness, and malnutrition. In studies of adults, S/R have been found to decrease the negative responses to stressors and thereby also decrease negative effects on the body and health (Lynn, Paris, Frye, \& Schell, 2010; Mihaljević et al., 2011; Tartaro, Luecken, \& Gunn, 2005). There is evidence that adults may use $S / R$ to assist them in managing stressors, which has contributed to improved immune and physiological functioning (Dedert et al., 2004; Ironson et al., 2002; 
King, Mainous, \& Pearson, 2002; Lynn et al., 2010; Mihaljević et al., 2011; Tartaro et al., 2005).

The purpose of this literature review was to examine the role of S/R among persons living with SCD. Consistent with an understanding that spirituality is an enduring dimension of persons across the life span, the approach of this review was to gather data regarding persons of all ages rather than to prematurely separate literature by age-group. This broad view will provide some understanding of patterns of S/R use among various age-groups of persons with SCD and help identify gaps and areas for future research. Consideration of S/R may also help providers give holistic care.

\section{Method}

Studies were sought that examined S/R among children, adolescents, and adults with SCD. Thus, studies were included in this review if they met the following criteria: (a) examined $S / R$ in persons with SCD, (b) examined S/R among parents of adolescents and/or children with SCD, (c) were quantitative or qualitative articles, and (d) were published in peer-reviewed journals. The databases searched were Cumulative Index to Nursing and Allied Health Literature, Health Source Nursing/Academic, ProQuest Health Module, PsycINFO, Medline, PubMed, and the American Theological Library Association. The search strategy used in this review included the following string of terms: "sickle cell disease" + "spirit*" (for spiritual or spirituality) + "adolescen*" (for adolescent, adolescents, or adolescence) or "x . . ." + "adult*" (for adult or adults) + child (for child or children). The alternate term included the following: "children," "religio*" (for religion, religious, or religiosity), "health," "pediatric," and "coping." A total of 89 articles were retrieved. Eleven articles met the inclusion criteria and were included in this review.

All 11 studies addressed S/R and SCD; 1 reported on S/R in children with SCD, 3 included adolescents and children with SCD, 1 included only adolescents with SCD, and 6 included adults 18 years and older (see Tables 1 and 2). In reviewing the 11 studies, four themes were identified: $S / R$ as sources for coping, $S / R$ enhances pain management, $S / R$ influences health care utilization, and $S / R$ improves quality of life (QOL).

Journal of Holistic Nursing, Vol. 34, No. 4 (November 29, 2015) pp. 351-360. DOI. This article is (C) SAGE Publications and permission has been granted for this version to appear in e-Publications@Marquette. SAGE Publications does not grant permission for this article to be further copied/distributed or hosted elsewhere without the express permission from SAGE Publications. 
NOT THE PUBLISHED VERSION; this is the author's final, peer-reviewed manuscript. The published version may be accessed by following the link in the citation at the bottom of the page.

Table 1. Spirituality and Religiosity in Children and Adolescents with SCD

Table 1. Spirituality and Peligiosity in Children and Adolescents With SCD

\begin{tabular}{|c|c|c|c|}
\hline Study & Simple & Design & Primary Results \\
\hline $\begin{array}{l}\text { Anie, Stepsoe, Ball, } \\
\text { Dick, and Smalling } \\
\text { (2002) }\end{array}$ & $\begin{array}{l}N=67 ; \text { ages } 7.15 \text { years; } 55 \% \\
\text { male, } 61 \% \text { African, } 34 \% \\
\text { Caribbean, } 5 \% \text { Mediterranean }\end{array}$ & Cross-sectional & $\begin{array}{l}\text { Praving and hoping most commonly used } \\
\text { active coping measures; active coping } \\
\text { directly correlated with increased use of } \\
\text { bealth care resurces; active coping not } \\
\text { related to pain }\end{array}$ \\
\hline Cotton et al. (2009) & $\begin{array}{l}N=48 ; \text { ages } 11.19 \text { years; } 48 \% \\
\text { male, } 98 \% \text { African American; } \\
N=42 \text {, parents' mean age } 32 \\
\text { years, } 95 \% \text { female, } 98 \% \\
\text { African American }\end{array}$ & Mixed-methods & $\begin{array}{l}\text { Adolescent participants and parents } \\
\text { demonstrated high levels of faith and } \\
\text { religious practices }\end{array}$ \\
\hline $\begin{array}{l}\text { Cotton, Grossoehme, } \\
\text { and McGrady (2012) }\end{array}$ & $\begin{array}{l}\mathrm{N}=19 ; \text { ages } 5.10 \text { years; } 53 \% \\
\text { female, } 100 \% \text { African } \\
\text { American }\end{array}$ & $\begin{array}{l}\text { Qualitative, } \\
\text { semistructured } \\
\text { interviews, drawings }\end{array}$ & $\begin{array}{l}\text { Children deseribed God as a functional God } \\
\text { (provided practicul care), emotional God } \\
\text { (provided confort when in pain), or both; }\end{array}$ \\
\hline $\begin{array}{l}\text { Sibinga, Shindell, } \\
\text { Casella, Duggan, } \\
\text { and Wilson (2006) }\end{array}$ & $\begin{array}{l}N=57 \text {; children mean age } 8 \\
\text { years; } 518 \text { male; } N=57 \text {; } \\
\text { parents' ages } 15-65 ; \text { males and } \\
\text { females, } 93 \% \text { African American }\end{array}$ & Cross-sectional & $\begin{array}{l}\text { prayer was common coping strategy for } \\
\text { stressful esperiences } 425 \text { of parents used } \\
\text { bioenergetic methods including prayer and } \\
\text { spiritual healing. Parents more likely to use } \\
\text { prayer and spiritual healing with their } \\
\text { children who were older, had severe SCD } \\
\text { symptoms, and had a higher perceived } \\
\text { impact of SCD on their child life. }\end{array}$ \\
\hline Yoon and Black (2006) & $\begin{array}{l}\mathrm{N}=62 ; \text { parents' ages } 16-74 \\
\text { years; } 81 \% \text { female, } 795 \\
\text { African American }\end{array}$ & Cross-sectional & $\begin{array}{l}\text { Increased use of pain medications by } \\
\text { children was related to increased use of } \\
\text { therapies such as praser, spiritual bealing. } \\
\text { massage, and relaxation }\end{array}$ \\
\hline
\end{tabular}

Noter $\mathrm{SCD}=$ sickle cell disease.

Table 2. Spirituality and Religiosity in Adults with SCD

Table 2. Spirituality and Religiosity in Adults With SCD

\begin{tabular}{|c|c|c|c|}
\hline Study & Sample & Design & Primary Results \\
\hline Adepbola $\{2011\}$ & $\begin{array}{l}N=90 \text {; ages } 218 \text { years: } \\
74 \% \text { female }\end{array}$ & $\begin{array}{l}\text { Descriptive correla- } \\
\text { tional }\end{array}$ & $\begin{array}{l}\text { Spirituality and QOL significantly correlated; } \\
\text { spirituality and self-efficacy predicted QOL; } \\
\text { spirituality and self-efficacy accounted for } \\
\text { more than half of the variance in QOL. }\end{array}$ \\
\hline Bediako et al. $\{2011\}$ & $\begin{array}{l}N=93 \text {; ages } \geq 18 \text { years: } \\
\text { males and females }\end{array}$ & Cross-sectional & $\begin{array}{l}\text { Positive religious coping significantly related to } \\
\text { less hospital admicsions }\end{array}$ \\
\hline $\begin{array}{l}\text { Cooper-Effa, Blaunt, } \\
\text { Kaskow, Rothenberg, } \\
\text { and Echman (2001) }\end{array}$ & $\begin{array}{l}N=71 \text {, adules mean age } \\
35 \text { years: } 83 \% \text { fenale }\end{array}$ & Crrssisectional & $\begin{array}{l}\text { Spiritual well-being was correlated with per- } \\
\text { ception of life control; spirituality signifi. } \\
\text { cantly related to } \text { QOLL; existential well-being } \\
\text { is associated with managing pain }\end{array}$ \\
\hline Harrison er al, $\{2005\rangle$. & $\begin{array}{l}N=50 \text {; ages } 18.70 \text { year } 5 ; \\
22 \text { males and } 28 \\
\text { females; } 100 \% \text { African } \\
\text { American }\end{array}$ & Cross-sectional & $\begin{array}{l}\text { Incressed refigious involvement fehurch } \\
\text { attendance) significantly related to less pain }\end{array}$ \\
\hline $\begin{array}{l}\text { Mann-Jiles and Morris } \\
\text { (2009) }\end{array}$ & $\begin{array}{l}\mathrm{X}=62 \text {; ages } \geq 18 \text { years; } \\
60 \% \text { female, } 895 \text { African } \\
\text { Arecrican }\end{array}$ & Cross-secticonal & $\begin{array}{l}\text { Inereased spirituality significantly related to } \\
\text { increased QOL. }\end{array}$ \\
\hline $\begin{array}{l}\text { O'Connell-Edwards } \\
\text { et al. }(2009)\end{array}$ & $\begin{array}{l}N=67 ; \text { ages } 18-70 \text { years: } \\
55 \% \text { female }\end{array}$ & Cross-sectional & $\begin{array}{l}\text { Moderate prayer significantly related to less. } \\
\text { anviety; low to moderate church astendance } \\
\text { related to shorter hospital stays, fewer emer- } \\
\text { gency department visits, and fewer hospitali- } \\
\text { zations. }\end{array}$ \\
\hline
\end{tabular}

Note: $\mathrm{SCD}=$ sic:lle cell disease; $\mathrm{QOL}=$ = quality of life.

Journal of Holistic Nursing, Vol. 34, No. 4 (November 29, 2015) pp. 351-360. DOI. This article is (C) SAGE Publications and permission has been granted for this version to appear in e-Publications@Marquette. SAGE Publications does not grant permission for this article to be further copied/distributed or hosted elsewhere without the express permission from SAGE Publications. 


\section{Theme 1: Spirituality and Religiosity as Sources for Coping}

Adolescents and adults relied on their S/R when managing their SCD. S/R were significant in coping as reported by parents who used them with their children or adolescents with SCD (Sibinga, Shindell, Casella, Duggan, \& Wilson, 2006; Yoon \& Black, 2006). Two research articles discussed S/R used by caregivers of adolescents and children with SCD as an approach to coping and enhancing clinical care (Sibinga et al., 2006; Yoon \& Black, 2006). In fact, parents were interested in discussing S/R with regard to their children's health, but some felt providers were not interested (Sibinga et al., 2006; Yoon \& Black, 2006).

Prayer and spiritual healing were the S/R practices used most often by parents as interventions for their children (Sibinga et al., 2006). Prayer is an active process of communicating to God or A Higher Being. Spiritual healing is a process of a person directing healing power toward another (National Federation of Healers, 2014). Prayer and spiritual healing were used more frequently by parents for their adolescents and children who used two or more analgesics (Yoon \& Black, 2006). Parents were more likely to use prayer and spiritual healing with their children who were older (mean ages of 9.7 years vs. 6.4 years), had higher scores on SCD severity scale (odds ratio [OR] $1.33,95 \%$ confidence intervals $[1.02,1.72], p=.03)$, had a higher perceived impact of SCD on the child's life ("tremendous" vs. "no" impact, $p=.02$ ), and had multiple hospitalizations within the preceding 12 months ( $p=.05$; Sibinga et al., 2006). Parents who used prayer and spiritual healing for themselves and those who had a higher level of education were more likely to use prayer and spiritual healing with their SCD affected children.

Using a mixed-methods approach, Cotton et al. (2009) surveyed 48 adolescents about how they used S/R to cope with their illness and living with SCD. In addition, 42 parents of adolescents living with SCD were surveyed to determine how the parents used S/R to cope with their children's illnesses. Of the 37 adolescents completing quantitative surveys, $35 \%(n=13)$ prayed once or more daily for symptom management, $64 \%(n=24)$ prayed a minimum of once per week, and 
$51 \%(n=19)$ reported attending religious services a minimum of once per week (Cotton et al., 2009). Approximately, 73\% of adolescents ( $n$ $=27)$ asked for forgiveness of sins, $67 \%(n=25)$ looked for a stronger connection with God/Higher Power, and 64\% $(n=24)$ sought God's love and care. Adolescents reported greater use of positive religious coping than negative religious coping (a range of $22 \%$ to $47 \%$ reported using one of seven listed positive coping strategy types "a great deal"). Parents also reported greater use of positive religious coping than negative religious coping ( $29 \%$ to $62 \%$ reported using one of the seven listed positive coping strategy types "a great deal"). When comparing teens with parents, adolescents reported greater negative religious coping than nonmatched parents, $t(76)=-2.01, p$ $<.05$. Eleven adolescents completed the qualitative interviews and all reported belief in God. Adolescents described religion as guiding them when making decisions about whether to engage in risky behaviors.

In a study of children with $S C D$, prayer was identified as a religious coping strategy used to manage their SCD. More than half of the children employed religious coping to manage and provide comfort when they were sick or in pain and to give meaning during stressful events related to SCD (Cotton, Grossoehme, \& McGrady, 2012). Children described God as a functional God (provided practical care), an emotional God (provided comfort when in pain), or both. A couple of the children reported being disappointed by God's response or lack of response to their illness. Prayer was a common coping strategy and religious methods for coping gave meaning when facing stressful experiences.

S/R were used as a source of coping in adults. Praying, bible study, and church attendance were religious methods used for coping with SCD (Bediako et al., 2011; Cooper-Effa, Blount, Kaslow, Rothenberg, \& Eckman, 2001; Harrison et al., 2005; O'ConnellEdwards et al., 2009). Adult studies focused on examining the association of $S / R$ with specific outcomes affecting health (Harrison et al., 2005; O'Connell-Edwards et al., 2009). The desire of parents and guardians to discuss $S / R$ and managing illness with their health providers was not addressed.

Journal of Holistic Nursing, Vol. 34, No. 4 (November 29, 2015) pp. 351-360. DOI. This article is (C) SAGE Publications and permission has been granted for this version to appear in e-Publications@Marquette. SAGE Publications does not grant permission for this article to be further copied/distributed or hosted elsewhere without the express permission from SAGE Publications. 


\section{Theme 2: Spirituality and Religiosity Enhances Pain Management}

S/R were often used by individuals or their parents to handle their pain. This theme emerged in six studies. Three studies addressed $\mathrm{S} / \mathrm{R}$ and pain management in adults (Cooper-Effa et al., 2001; Harrison et al., 2005; O'Connell-Edwards et al., 2009). Three studies addressed S/R and pain management in adolescents, children, and caregivers (Anie, Stepsoe, Ball, Dick, \& Smalling, 2002; Sibinga et al., 2006; Yoon \& Black, 2006).

Adolescents and children with SCD used prayer and hope to cope with their SCD pain. Adolescents and children who had more severe pain were more likely to use more passive coping (resting, heat/cold/massage, taking fluids). Of active coping strategies (e.g., ignoring pain sensations, calming self-statements, increasing activity, diverting attention, reinterpreting pain statements, and praying and hoping), children and adolescents in one study used prayer and hope the most often (Anie et al., 2002). In a second study, adolescents with SCD used prayer and spiritual healing most often (Cotton et al., 2009). Coping strategies used less often than prayer and hope among children and adolescents included calming self-statements, diverting attention, and reinterpreting pain sensations (Anie et al., 2002). Among studies comprising adults, the use of S/R were associated with increased coping with SCD pain and decreased reports of pain (Cooper-Effa et al., 2001; Harrison et al., 2005). Spiritual and religious practices, such as church attendance and moderate frequency of prayer, were associated with the lowest scores for pain severity in adults (Harrison et al., 2005; O’Connell-Edwards et al., 2009).

Caregivers used S/R in caring for their adolescents and children affected by SCD (Yoon \& Black, 2006). In this study, more than $70 \%$ of caregivers $(n=44)$ used some form of therapy such as prayer, spiritual healing, massage therapy, relaxation, administering megavitamins, or administering herbal products (Yoon \& Black, 2006). Of these therapies, more than $70 \%$ of the caregivers used prayer, and over 50\% used spiritual healing (Yoon \& Black, 2006). Caregivers used $\mathrm{S} / \mathrm{R}$ more often in caring for their SCD-affected children who were over 13 years of age (Yoon \& Black, 2006). The authors provided as permission has been granted for this version to appear in e-Publications@Marquette. SAGE Publications does not grant permission for this article to be further copied/distributed or hosted elsewhere without the express permission from SAGE Publications. 
possible explanations that parents were concerned about their adolescents' pain severity and employing more than one intervention or were concerned over opioid use. For children, adolescents and caregivers, increased use of pain medication and SCD severity were associated with greater use of S/R (Sibinga et al., 2006; Yoon \& Black, 2006).

\section{Theme 3: Spirituality and Religiosity Influences Health Care Utilization}

Emergency room admissions and hospitalizations were related to use of S/R. This theme was identified in three studies. In one study, adolescents and children using active coping (including spiritual and religious strategies) to manage pain were more likely to use health services. The authors propose that greater use of health services may be a result of parents participating in health maintenance initiatives on behalf of their children (Anie et al., 2002). Persons with more pain were more likely to report that they used passive coping. In a second study with adults, participants who indicated having had more experiences of positive religious coping demonstrated fewer hospitalizations over a 12-month period (Bediako et al., 2011). In a third with adults, frequency of church attendance was directly associated with health care utilization, including number of hospitalizations and number of days in the hospital ( $\mathrm{O}^{\prime}$ Connell-Edwards et al., 2009). In this study, low to moderate frequency church attendance was associated with less health care utilization, and a higher frequency of church attendance was associated with increased utilization (O'Connell-Edwards et al., 2009). Moderate frequency prayer had better behavioral health outcomes, such as less anger and less hostility, in comparison to less frequency or high frequency of prayer (O'Connell-Edwards et al., 2009).

\section{Theme 4: Spirituality and Religiosity Improve Quality of Life}

In general, perception of QOL was improved among individuals who used spiritualty and religiosity in adolescents and adults. QOL was examined in one study for adolescents (Cotton et al., 2009) and two studies for adults, with findings supporting a positive relationship 
between spirituality and their perception of QOL (Adegbola, 2011; Mann-Jiles \& Morris, 2009). In one study, spirituality was associated with enhanced life satisfaction and enhanced life direction among adults (Cooper-Effa et al., 2001). In another study, health-related quality of life (HRQOL) in adolescents with SCD was evaluated and school performance was evaluated in relation to overall spirituality (Cotton et al., 2009). Higher spirituality was associated with better school performance. Two quantitative descriptive studies examined QOL in patients with SCD, aged 18 and older. The first study compared QOL between healthy populations and those living with SCD. The mean Quality of Life Scale score (QOLS) for healthy populations was 90, whereas for patients with SCD, the mean QOLS score was 83.6 (score range 16-112; Mann-Jiles \& Morris, 2009). QOL was directly related to the individual's perception of spirituality, $t(59)=-2.970, p<.05$ (Mann-Jiles \& Morris, 2009). Those with higher levels of spirituality also had higher QOL scores. In a second study in which QOL was explored, the relationship between QOL, spirituality, and self-efficacy was examined among adults (Adegbola, 2011). There was a positive and significant relationship between the perception of QOL and spirituality, $r(88)=0.68, p<.05$. Spirituality and self-efficacy predicted QOL.

\section{Discussion}

Overall, 11 articles were examined to report on the state of the literature addressing S/R in persons living with SCD. An analysis of findings supports the use of S/R for persons living with SCD. To effectively promote holistic well-being, health care providers should consider the manner in which $S / R$ is used across the life span, how $S / R$ is associated with illness experiences, in what way $S / R$ affects health outcomes, and the relationship of S/R to QOL.

\section{Spirituality, Religiosity, and Developmental Considerations}

Data from children and adolescents with SCD were not always obtained, which points to a gap in the literature (Sibinga et al., 2006; Yoon \& Black, 2006). Only one study examined S/R specifically among adolescents (Cotton et al., 2009). Understanding why adolescents permission has been granted for this version to appear in e-Publications@Marquette. SAGE Publications does not grant permission for this article to be further copied/distributed or hosted elsewhere without the express permission from SAGE Publications. 
reported higher levels of negative religious coping than nonmatched parents/guardians may likely assist caregivers and health care providers in supporting adolescents (Cotton et al., 2009). Research addressing adolescents and adults living with SCD specifically and obtaining their perspectives is warranted. Use of $S / R$ as types of alternative therapies was provided, but adolescents' perspectives may complement parental reports and guide further inquiry (Sibinga et al., 2006; Yoon \& Black, 2006). Conducting longitudinal studies will allow for further assessment of the relational influence of $S / R$ to coping for the individual or groups over time. The relevance of $S / R$ to coping can provide additional insight into the mechanisms by which $S / R$ influences coping as well as offer developmental considerations. In addition, the use of S/R during various illness experiences over time can be observed. In two studies, prayer and spiritual healing were explored but not conceptually defined (Sibinga et al., 2006; Yoon \& Black, 2006). Praying and hoping were combined as an active coping strategy but not defined, whether as separate concepts or as a combined concept (Anie et al., 2002). Lack of definitions and combining concepts may impede the understanding of how each is relevant to S/R and coping with SCD. This is critical to establish when working with children and adolescents who may need assistance articulating their spiritual and religious needs.

\section{Understanding the Association Between Pain Experiences, Spirituality, and Religiosity}

Consistent with the literature, S/R were associated with managing the pain experiences of children and adolescents living with SCD (Anie et al., 2002). Addressing pain specifically as a symptom of SCD and the relevance to S/R were more common in the studies conducted with adults (Cooper-Effa et al., 2001; Harrison et al., 2005; O'Connell-Edwards et al., 2009). Children and adolescents using two or more pain medications were more likely to use spiritual and religious alternative therapies, but there was no indication of the use of pain assessments by caregivers and timing of alternative therapies (Yoon \& Black, 2006). Persons with more severe disease and pain have reported more use of $S / R$ to cope. Further exploring $S / R$ and the relationship to pain experiences is warranted. Documentation of pain experiences to include a complete pain assessment, with consideration

Journal of Holistic Nursing, Vol. 34, No. 4 (November 29, 2015) pp. 351-360. DOI. This article is (C) SAGE Publications and permission has been granted for this version to appear in e-Publications@Marquette. SAGE Publications does not grant permission for this article to be further copied/distributed or hosted elsewhere without the express permission from SAGE Publications. 
of $S / R$, may provide valuable information. How S/R affect outcomes such as pain severity and SCD pain crisis was not specifically investigated in the adolescent population. Greater understanding of the use of S/R to cope with pain is needed, specifically in adolescents and adults living with SCD. Exploring why parents were more likely to use alternative modalities on behalf of their children requiring more than one medication is significant. As the severity of illness and pain experiences increases, a holistic approach to managing pain may be effective when individualizing nursing care.

\section{Spirituality, Religiosity, and Health Outcomes}

In line with the literature, drawing on $S / R$ beliefs to manage symptoms and cope with SCD was common among children, adolescents, and adults living with SCD and caregivers on behalf of their children living with SCD (Anie et al., 2002; Cooper-Effa et al., 2001; Cotton et al., 2009; Cotton et al., 2012; Harrison et al., 2005; O'Connell-Edwards et al., 2009; Sibinga et al., 2006; Yoon \& Black, 2006). Further assessment and follow-up on the parents' desires to discuss S/R with their child's/adolescent's health care provider is warranted. An assessment inclusive of the child's/adolescent's beliefs should precede customizing the plan of care.

The influence of S/R on health care utilization was addressed in the literature. Use of S/R was directly correlated to increased use of health care services, suggesting that S/R may directly affect perception of health maintenance and actions taken to improve health outcomes (Anie et al., 2002). Positive religious coping was found to be related to fewer hospital admissions among adults (Bediako et al., 2011). The readmission rate for those with SCD in comparison to other chronic disease populations affirms the need to further explore the effects of S/R on health care utilization (Elixhauser \& Steiner, 2013). The relationship between $S / R$ and health care utilization for persons with SCD is unclear, although intriguing and worthy of further study. In the situation of limited medical options to cure SCD, prevent worsening of the condition, and alleviate symptoms, persons with severe disease may turn more readily to S/R to improve their wellbeing. It may also indicate that the more individuals relied on their $S / R$ to cope, the more likely they were to seek out health resources in permission has been granted for this version to appear in e-Publications@Marquette. SAGE Publications does not grant permission for this article to be further copied/distributed or hosted elsewhere without the express permission from SAGE Publications. 
general. There may be specific characteristics, such as healthy coping behaviors, of those engaged in moderate spiritual and religious coping that caused them to use health care resources more often.

\section{An Integrative Approach and Quality of Life}

In accordance with the literature, $\mathrm{S} / \mathrm{R}$ does improve QOL. QOL was examined in one study for adolescents (Cotton et al., 2009) and two studies for adults, with findings supporting a positive relationship between spirituality and their perception of QOL (Adegbola, 2011; Mann-Jiles \& Morris, 2009). One study conducted with adolescents demonstrated a positive relationship between spirituality and school performance (Cotton et al., 2009). School performance is one item used to assess HRQOL. When evaluating QOL and HRQOL, the S/R of children, adolescents, and adults should be considered to effectively treat the whole person and promote a better QOL. Additional studies examining the relationship between $\mathrm{QOL}$ and $\mathrm{S} / \mathrm{R}$ across the life span is warranted. Examining the effects of addressing $S / R$ during the early years for those living with $S C D$ and how this may affect their adult life is worth exploring. The use of an integrative model of care inclusive of $\mathrm{S} / \mathrm{R}$ provides a comprehensive approach for managing illness.

\section{Limitations of the Literature}

Research exploring $\mathrm{S} / \mathrm{R}$ in children, adolescents, and adults living with SCD provided limited quantitative data. This was specifically true with regard to adolescents. There was one mixed-methods study conducted with adolescents with SCD (Cotton et al., 2009). Other studies explored adolescents and children together (Anie et al., 2002; Yoon \& Black, 2006). Most of the studies reviewed were not conducted within the past 5 years. It was also noted that there were no studies conducted with the young adult population exclusively (aged 18-21 years). Given the challenges that adolescents and young adults encounter, such as coping with the complexities of their SCD, fears of transitioning to adult care, and few adult providers specialized to care for this population, exploring $S / R$ as a resource to help them manage their SCD certainly warrants further investigation.

Journal of Holistic Nursing, Vol. 34, No. 4 (November 29, 2015) pp. 351-360. DOI. This article is (C) SAGE Publications and permission has been granted for this version to appear in e-Publications@Marquette. SAGE Publications does not grant permission for this article to be further copied/distributed or hosted elsewhere without the express permission from SAGE Publications. 


\section{Implications and Conclusions}

Four themes were identified for the role $S / R$ serves for persons living with SCD: S/R as sources for coping, S/R enhances pain management, $S / R$ influences health care utilization, and $S / R$ improves QOL. For health care providers, it is vital to be aware of the individuality of persons with SCD and to include their opinions and values in order to provide appropriate holistic care. S/R coping may include bible study, prayer, church attendance, spiritual healing, and other strategies. To identify S/R in the context of health and illness, a spiritual assessment is warranted. Completing a spiritual assessment in the clinic or hospital setting may present the provider with insight on S/R preferences and any areas of concern or distress experienced, particularly in persons living with a chronic illness. Children, adolescents, and adults living with a chronic illness and/or chronic pain should receive a spiritual assessment more often, as changes in their health status may result in changes to their $S / R$. This review of literature revealed that adolescents, adults, and caregivers of children with SCD are willing to provide information regarding their S/R preferences when acknowledged. Health care providers should be prepared to discuss S/R with adolescents and adults and their families.

It is imperative to gain an understanding of adolescents' perspectives rather than the parents' alone. When comparing spiritual preferences, the responses of adolescents may differ from their parents' perceptions (Cotton et al., 2009). Spiritual and religious beliefs of parents influence their children, but during adolescence changes take place. Adolescents seek to establish their sense of identity, and during these developmental transitions, their spiritual and religious preferences may or may not resemble the preferences of their parents. Following up on the concerns and preferences of adolescents and allowing time for discussion can prevent conflict within adolescents and between adolescents and adults. Evaluating the S/R of adolescents can offer information specific to their life experiences.

Individuals and families may be referred as needed to practitioners such as a chaplain, psychologist, or social worker who can address their S/R concerns. Providers should also consider accommodating an integrative approach to care and consult with other permission has been granted for this version to appear in e-Publications@Marquette. SAGE Publications does not grant permission for this article to be further copied/distributed or hosted elsewhere without the express permission from SAGE Publications. 
practitioners skilled in providing spiritual care. Adolescents, adults, and caregivers of children with SCD may also be encouraged to contact their personal spiritual care provider, such as a pastor, rabbi, or other religious leader. Permission should be obtained from the family in the event that medical information is shared with the spiritual provider in order to provide personalized and supportive spiritual care. Including $\mathrm{S} / \mathrm{R}$ in the care provided allows for an appropriate assessment and communicates that the provider acknowledges and respects their beliefs.

By exploring S/R in the context of living with SCD, the information gained will inform providers of potential resources and spiritual strengths that individuals may draw from and use to cope with their illness. Understanding the influence of S/R on illness and health across the life span will assist in individualizing care. This may apply to care responsibilities and life transitions such as approach to self-management, emerging as a young adult, and making decisions regarding family planning. Providers can assist in managing unique spiritual concerns and develop interventions to address spiritual needs. This involvement is a step toward promoting effective coping to ameliorate symptoms of SCD, provide holistic care, and improve QOL. Addressing inequalities in care is initiated when providers explore factors unique for each patient and significant concepts to incorporate into the plan of care.

In persons with $S C D, S / R$ is worth exploring. Research studies to further investigate the influence of $S / R$ among children, adolescents, and adults are critical to understanding the concept from a developmental perspective. This review was a preliminary step in conducting a qualitative study examining $S / R$ in adolescents living with $\mathrm{SCD}$. Further exploring the association of S/R with coping, pain management, health care utilization, and QOL will provide direction for intervening and improving health and well-being among persons living with SCD. 
NOT THE PUBLISHED VERSION; this is the author's final, peer-reviewed manuscript. The published version may be accessed by following the link in the citation at the bottom of the page.

\section{About the Authors:}

Dora Clayton-Jones, PhD, RN, CPNP-PC, is an Assistant Professor at the University of Wisconsin-Milwaukee with research interests in selfmanagement of chronic conditions during adolescence, spirituality and health, integrative medicine, and health equity.

Kristin Haglund, PhD, RN, FNP-BC is an Associate Professor at Marquette University with research interests in healthy interpersonal relationships, arts-based interventions, spirituality, and improving health of children and adolescents with chronic conditions.

\section{References}

Adegbola M. (2011). Spirituality, self-efficacy, and quality of life among adults with sickle cell disease. Southern Online Journal of Nursing Research, 11(1), 1-16.

Anie K. A., Stepsoe A., Ball S., Dick M., Smalling B. M. (2002). Coping and health service utilisation in a UK study of paediatric sickle cell pain. Archives of Disease in Childhood, 86, 325-329.

Aygun B. (2011). Sickle cell disease. In Fisher M., Alderman E., Kreipe R., Rosenfeld W. (Eds.). Textbook of adolescent health care (pp. 10381050). Elk Grove Village, IL: American Academy of Pediatrics.

Bediako S. M., Lattimer L., Haywood C. Jr., Ratanawongsa N., Lanzkron S., Beach M. C. (2011). Religious coping and hospital admissions among adults with sickle cell disease. Journal of Behavioral Medicine, 34, 120127.

Benson P. L., Roehlkepartain E. C., Rude S. P. (2003). Spiritual development in childhood and adolescence: Toward a field of inquiry. Applied Developmental Science, 7, 204-212.

Cohen A. B., Koenig H. G. (2003). Religion, religiosity and spirituality in the biopsychosocial model of health and ageing. Ageing International, 28, 215-241.

Cohen S., Kessler R. C., Gordon U. L. (1995). Strategies for measuring stress in studies of psychiatric and physical disorder. In Cohen S., Kessler R. C., Gordon U. L. (Eds.), Measuring stress: A guide for health and social scientists (pp. 3-26). New York, NY: Oxford University Press.

Cooper-Effa M., Blount W., Kaslow N., Rothenberg R., Eckman J. (2001). Role of spirituality in patients with sickle cell disease. Journal of the American Board of Family Practice, 14, 116-122.

Cotton S., Grossoehme D., McGrady M. E. (2012). Religious coping and the use of prayer in children with sickle cell disease. Pediatric Blood \& Cancer, 58, 244-249.

Journal of Holistic Nursing, Vol. 34, No. 4 (November 29, 2015) pp. 351-360. DOI. This article is (C) SAGE Publications and permission has been granted for this version to appear in e-Publications@Marquette. SAGE Publications does not grant permission for this article to be further copied/distributed or hosted elsewhere without the express permission from SAGE Publications. 
Cotton S., Grossoehme D., Rosenthal S. L., McGrath M. E., Roberts Y. H., Hines J., Tsevat J. (2009). Religious/spiritual coping in adolescents with sickle cell disease: A pilot study. Journal of Pediatric Hematology Oncology, 31, 313-318.

Dedert E. A., Studts J. L., Weissbecker I., Salmon P. G., Banis P. L., Sephton S. E. (2004). Religiosity may help preserve the cortisol rhythm in women with stress-related illness. International Journal of Psychiatry in Medicine, 34, 61-77.

Elixhauser A., Steiner C. (2013). Readmissions to U.S. hospitals by diagnosis, 2010 (Statistical Brief No. 153). Retrieved from http://www.hcupus.ahrq.gov/reports/statbriefs/sb153.pdf

Harrison M. O., Edwards C. L., Koenig H. G., Bosworth H. B., Decastro L., Wood M. (2005). Religiosity/spirituality and pain in patients with sickle cell disease. Chicago Journal of Nervous and Mental Disease, 193, 250-257.

Ignatavicus D. D., Workman M. L. (2013). Medical-surgical nursing: Patientcentered collaborative care (7th ed.). St. Louis, MI: Elsevier.

Ironson G., Solomon G. F., Balbin E. G., O'Cleirigh C., George A., Kumar M., Woods T. (2002). The Ironson-Woods spirituality/religiousness index is associated with long survival, health behaviors, less distress, and low cortisol in people with HIV/AIDS. Annals of Behavioral Medicine, 24(1), 34-48.

Kauf T. L., Coates T. D., Huazhi L., Mody-Patel N., Hartzema A. G. (2009). The costs of health care for children and adults with sickle cell disease. American Journal of Hematology, 84, 323-327.

King D. E., Mainous A. G., Pearson W. S. (2002). C-reactive protein, diabetes, and attendance at religious services. Diabetes Care, 25, 1172-1176.

Koenig H. G., Cohen H. J. (2002). Psychosocial factors, immunity, and wound healing. In Koenig H. G., Cohen H. J. (Eds.), The link between religion and health: Psychoneuroimmunology and the faith factor (pp. 124138). New York, NY: Oxford University Press.

Koenig H. G., King D. E., Carson V. B. (2012). Handbook of religion and health (5th ed.). New York, NY: Oxford University Press.

Larson D. B., Swyers J. P., McCullough M. E. (1998). Scientific research on spirituality and health: A consensus report. Rockville, MD: National Institute for Healthcare Research.

Lynn C. D., Paris J., Frye C. A., Schell L. M. (2010). Salivary alpha-amylase and cortisol among Pentecostals on a worship and nonworship day. American Journal of Human Biology, 22, 819-822.

Mahoney A., Pendleton S., Ihrke S. (2006). Religious coping by children and adolescents: Unexplored territory in the realm of spiritual development. In Roehlkepartain E. C., Ebstyne-King P. E., Wagener L.,

Journal of Holistic Nursing, Vol. 34, No. 4 (November 29, 2015) pp. 351-360. DOI. This article is (C) SAGE Publications and permission has been granted for this version to appear in e-Publications@Marquette. SAGE Publications does not grant permission for this article to be further copied/distributed or hosted elsewhere without the express permission from SAGE Publications. 
NOT THE PUBLISHED VERSION; this is the author's final, peer-reviewed manuscript. The published version may be accessed by following the link in the citation at the bottom of the page.

Benson P. L. (Eds.), The handbook of spiritual development in childhood and adolescence (pp. 341-354). Thousand Oaks, CA: Sage.

Mann-Jiles V., Morris D. L. (2009). Quality of life of adult patients with sickle cell disease. Journal of the American Academy of Nurse Practitioners, 21, 340-349.

Mihaljević S., Vuksan-ćusa B., Marcinko D., Koić E., Kusević Z., Jakovljević M. (2011). Spiritual well-being, cortisol, and suicidality in Croatian war veterans suffering from PTSD. Journal of Religion and Health, 50, 464473.

National Federation of Healers. (2014). What is spiritual healing? Retrieved from http://www.nfh.org.au/

National Institutes of Health. (2012). Genetics home reference: Your guide to understanding genetic conditions, sickle cell disease. Retrieved from http://ghr.nlm.nih.gov/condition/sickle-cell-disease

O'Connell-Edwards C. F., Edwards C. L., Pearce M., Waccholtz A. B., Wood M., Muhammad M., . . . Robinson E. (2009). Religious coping and pain associated with sickle cell disease: Exploration of a non-linear model. Journal of African American Studies, 13, 1-13.

Pargament K. I. (1997). The psychology of religion and coping: Theory, research, practice. New York, NY: Guilford Press.

Pargament K. I., Koenig H. G., Tarakeshwar N., Hahn J. (2004). Religious coping methods as predictors of psychological, physical, and spiritual outcomes among medically ill elderly patients: A two-year longitudinal study. Journal of Health Psychology, 9, 713-730.

Pinckney R. B., Stuart G. W. (2004). Adjustment difficulties of adolescents with sickle cell disease. Journal of Child and Adolescent Psychiatric Nursing, 17(1), 5-12.

Rees D. C., Williams T. N., Gladwin M. T. (2010). Sickle-cell disease. Lancet, 376, 2018-2031.

Schaefer J. (2010). Theology 6995: Independent study in adolescent spirituality and religiosity (Personal discussion with Jame Schaefer, PhD, Director, Marquette University, Milwaukee, WI).

Sibinga E. M., Shindell D. L., Casella J. F., Duggan A. K., Wilson M. H. (2006). Pediatric patients with sickle cell disease: Use of complementary and alternative therapies. Journal of Alternative and Complementary Medicine, 12, 291-298.

Steiner C. A., Miller J. L. (2006). Sickle cell disease patients in U.S. hospitals, 2004 (Statistical Brief No. 21). Retrieved from http://www.hcupus.ahrq.gov/reports/statbriefs/sb21.pdf

Tartaro J., Luecken L. J., Gunn H. E. (2005). Exploring heart and soul: Effects of religiosity/spirituality and gender on blood pressure and cortisol stress responses. Journal of Health Psychology, 10, 753-766.

Journal of Holistic Nursing, Vol. 34, No. 4 (November 29, 2015) pp. 351-360. DOI. This article is (C) SAGE Publications and permission has been granted for this version to appear in e-Publications@Marquette. SAGE Publications does not grant permission for this article to be further copied/distributed or hosted elsewhere without the express permission from SAGE Publications. 
NOT THE PUBLISHED VERSION; this is the author's final, peer-reviewed manuscript. The published version may be accessed by following the link in the citation at the bottom of the page.

Waldron-Perrine B., Rapport L. J., Hanks R. A., Lumley M., Meachen S. J., Hubbarth P. (2011). Religion and spirituality in rehabilitation outcomes among individuals with traumatic brain injury. Rehabilitation Psychology, 56, 107-116.

Yoon S. L., Black S. (2006). Comprehensive, integrative management of pain for patients with sickle-cell disease. Journal of Alternative and Complementary Medicine, 12, 995-1001.

Journal of Holistic Nursing, Vol. 34, No. 4 (November 29, 2015) pp. 351-360. DOI. This article is (C) SAGE Publications and permission has been granted for this version to appear in e-Publications@Marquette. SAGE Publications does not grant permission for this article to be further copied/distributed or hosted elsewhere without the express permission from SAGE Publications. 